\title{
Analisis Segmentasi dan Preferensi Konsumen Terhadap Pasar Tradisional dan Pasar Modern Menggunakan Binary Logistic Regression
}

\author{
Anindya Rachma Dwicahyani' ${ }^{1)}$, Benazir Imam Arif Muttaqin ${ }^{2)}$ \\ 1) Jurusan Teknik Industri, Institut Teknologi Adhi Tama Surabaya \\ 2) Jurusan Teknik Industri, Institut Teknologi Telkom Surabaya \\ anindya.dwicahyani@itats.ac.id
}

\begin{abstract}
Abstrak
Tidak dapat dipungkiri, sebagian masyarakat telah beralih pada penggunaan pasar modern dibandingkan pasar yang tradisional. Namun demikian, masyarakat Indonesia sangatlah beragam, mulai dari aspek demografis, pendidikan, dan kelompok perekonomiannya. Studi tentang pengaruh beberapa faktor-faktor tersebut terhadap keputusan dalam memilih pasar modern atau pasar tradisional merupakan fokus dari artikel ini. Pada artikel ini, digunakan binary logistic regression dengan dua variabel keputusan utama yaitu memilih pasar modern dan/atau memilih pasar tradisional. Keuntungan dari penggunaan regresi jenis ini adalah kita bisa mengukur kemungkinan seseorang dalam memilih alternatif tertentu. Pada artikel ini, sebanyak 200 sampel responden diambil di Kota Surakarta. Hasil yang didapatkan adalah $61 \%$ masih memilih pasar tradisional sebagai tempat berbelanja. Faktor yang cukup mempengaruhi keputusan konsumen dalam menentukan jenis pasar adalah pendidikan, pendapatan, dan jarak ke pasar. Berdasarkan hasil analisi, didapatkan simpulan bahwa persamaan binary logistic regression cukup handal dalam mengestimasi preferensi konsumen dalam memilih pasar tradisional atau modern.
\end{abstract}

Kata kunci: preferensi konsumen, pasar, binary logistic regression

\section{Pendahuluan}

Tingginya jumlah penduduk menyebabkan Indonesia memiliki permintaan yang tinggi terhadap kebutuhan pokok. Banyaknya permintaan akan kebutuhan pokok berimbas pula pada banyaknya jumlah pasar yang memasok kebutuhan pokok tersebut. Pada era modern seperti saat ini, bentuk pasar telah bergeser dari pasar tradisional menjadi pasar modern. Pasar modern adalah pasar yang dikelola dengan sistem manajemen modern. Pasar modern umumnya lebih mementingkan kenyamanan konsumen pada saat berbelanja, sehingga kebanyakan pasar modern dikemas secara menarik dan tertata rapi. Namun demikian, harga produk yang dibanderol oleh pasar modern umumnya lebih tinggi dibandingkan pasar tradisional, mengingat biaya operasionalnya yang lebih tinggi. Pasar modern yang banyak ditemui di berbagai daerah di Indonesia antara lain Hypermart, LotteMart, Superindo, Transmart, Alfamidi, Indomaret, Alfamart, dan lain-lain.

Berbeda dengan pasar modern, pasar tradisonal adalah pasar yang dikelola dengan sistem manajemen konvensional. Pasar tradisional terdiri dari banyak penjual yang berbeda-beda. Masingmasing penjual menawarkan barang dagangannya sendiri, sehingga setiap penjual memungkinkan memiliki harga yang berbeda. Pada pasar tradisional, umumnya terjadi transaksi tawar-menawar antara penjual dan pembeli, sehingga harganya tidak tetap dan terkadang menyebabkan suasana pasar ini ramai dan terlihat tidak teratur. Walaupun demikian, masih banyak masyarakat kita yang lebih memilih berbelanja di pasar tradisional dalam memenuhi kebutuhan sehari-hari. Banyak faktor yang mendorong hal tersebut. Menurut Dwicahyani, dkk (2019), selain faktor-faktor umum seperti kualitas barang, harga, kebiasaan, merk, dan lain-lain, preferensi konsumen dalam memilih produk juga dipengaruhi oleh bagaimana produk tersebut dibuat, apakah melalui aktivitas insourcing atau outsourcing. 
Regresi logistik merupakan model matematika yang dapat digunakan untuk memodelkan suatu hubungan antara variabel independent $\mathrm{X}$ yang biasanya berupa data yang berskala interval atau kategorik dan variabel dependent $\mathrm{Y}$ yang berupa bilangan biner (Hosmer dan Lemeshow, 1989). Variabel biner merupakan variabel yang hanya memiliki dua kategori, yaitu kategori 0 atau 1 yang masing-masing menyatakan kejadian gagal atau sukses. Berbeda dengan regresi linier, regresi logistik tidak mengasumsikan hubungan linier antara variabel indepeden dan variabel dependen. Penerapan analissi regresi logistik telah banyak dikembangkan oleh para peneliti untuk menyelesaikan masalah di berbagai sektor (Ketaren dan Sianturi, 2017). Menon dan Raj (2012) telah melaksanakan menggunakan regresi logistik untuk memodelkan perilaku konsumen dalam membeli mobil. Khaeri dan Prawitan (2018) menerapkan model regresi logistik biner dalam rangka mengkaji karakteristik wirausaha perempuan di Indonesia dan memahami faktor pendorong keterlibatan mereka di bidang wirausaha. Lebih lanjut, Kaygisiz, dkk. (2019) juga menggunakan model regresi logistik ini untuk mempelajari perilaku konsumen dalam pembelian daging.

Pada artikel ini, pengaruh dari masing-masing faktor dalam mempengaruhi segmentasi pasar modern dan tradisional ingin diuji. Dengan menggunakan regresi logistik, nilai probabilistik atau peluang masing-masing konsumen dalam menentukan tempat berbelanja antara pasar modern atau pasar tradisional dapat ditentukan. Dan pada akhirnya, segmentasi pasar modern dan pasar tradisional dapat dipetakan.

\section{Metode Penelitian (Methods)}

Secara garis besar, tahapan pelaksanaan penelitian terbagi menjadi identifikasi awal, tahap penentuan desain penelitian (penentuan populasi dan sampel), teknik dan metode sampling, serta desain kuesioner), tahap pengumpulan data, tahap pengolahan data dan analisis (rekapitulasi data, pengolahan data menggunakan software Marketing Engineering for Excel), serta tahap kesimpulan.

Penelitian ini dibatasi di wilayah Kota Surakarta. Kota ini sengaja dipilih, karena kota ini memiliki keragaman dan jumlah pasar modern dan pasar tradisional yang cukup banyak dan berimbang. Jumlah populasi di Kota Surakarta sebesar 557.251 orang. Karena jumlah populasi besar dan sulit menggunakan metode sampling probabilistik, maka metode sampling yang dipilih pada adalah dengan menggunakan metode non probability sampling. Teknik yang digunakan untuk memperoleh sampel dari responden adalah dengan menggabungkan antara quota sampling dan accidental sampling. Sampel diambil secara acak dan tiba-tiba dari responden. Apabila sudah memenuhi kuota tertentu maka pengambilan sampel dihentikan. Jumlah sampel yang diinginkan adalah sebesar 200 orang.

Pada penelitian ini, pemilihan tradisional market sebagai tempat berbelanja konsumen didefinisikan sebagai 0. Sedangkan pemilihan modern market sebagai tempat berbelanja konsumen didefinisikan sebagai 1. Pemilihan variabel independen yang diduga kuat mempengaruhi variabel dependen pada kasus ini didapatkan dari gabungan hasil pencarian informasi secara internal dan eksternal. Secara internal diperoleh dari hasil kreativitas tim peneliti, sedangkan secara eksternal diperoleh dari hasil wawancara dengan sebagian orang lain atau stakeholder yang berkaitan dengan kasus yang sedang diteliti ini. Pada penelitian ini, ditetapkan terdapat delapan variabel independen yang diduga mempengaruhi keputusan konsumen untuk memilih pasar tradisional atau pasar modern sebagai tempat berbelanja. Variabel-variabel tersebut antara lain jenis kelamin, umur, status perkawinan, pendidikan, pendapatan per bulan, jarak dari rumah ke pasar tradisional terdekat, jarak dari rumah ke pasar modern terdekat, serta jumlah anggota keluarga dalam satu rumah.

\section{Hasil dan Pembahasan}

\section{a. Rata-rata Nilai Variabel}

Berdasarkan hasil rekapitulasi responden, sebanyak 78 responden memilih pasar modern dan sebanyak 122 orang memilih pasar tradisional. Dari hasil data rekapitulasi responden diperoleh nilai rata-rata untuk semua masing-masing variabel mulai dari variabel jenis kelamin sampai jumlah anggota 
keluarga. Hasil ditunjukkan pada gambar 1. Berdasarkan gambar 1, diketahui bahwa pasar modern didominasi oleh responden yang lebih tua, status pernikahan dan pendidikan lebih tinggi, serta pendapatan yang lebih besar.

\begin{tabular}{|c|c|c|c|c|c|c|c|c|}
\hline \multicolumn{9}{|c|}{ Variable Averages for Chosen Alternatives } \\
\hline $\begin{array}{l}\text { Variables / } \\
\text { Alternatives }\end{array}$ & $\begin{array}{l}\text { Jenis } \\
\text { Kelamin }\end{array}$ & Umur & Status & Pendidikan & $\begin{array}{l}\text { Pendapatan per } \\
\text { Bulan }\end{array}$ & $\begin{array}{c}\text { Jarak dari } \\
\text { rumah ke } \\
\text { Traditional } \\
\text { Market } \\
\text { terdekat }\end{array}$ & $\begin{array}{l}\text { Jarak dari } \\
\text { rumah ke } \\
\text { Modern } \\
\text { Market } \\
\text { terdekat }\end{array}$ & $\begin{array}{c}\text { Jumlah } \\
\text { Anggota } \\
\text { Keluarga } \\
\text { dalam Satu } \\
\text { Rumah }\end{array}$ \\
\hline $\begin{array}{l}\text { Modern Market } \\
\text { Choice (1) }\end{array}$ & 0.526 & 30.692 & 0.487 & 4.038 & 24035897.436 & 8.745 & 7.228 & 3.077 \\
\hline $\begin{array}{c}\text { Traditional Market } \\
\text { Choice }(0) \\
\end{array}$ & 0.582 & 27.590 & 0.443 & 3.303 & 1315901.639 & 7.201 & 9.970 & 3.066 \\
\hline
\end{tabular}

Gambar 1. Rata-rata nilai variabel untuk setiap alternatif keputusan

\section{b. Pengaruh Masing-masing Variabel Independen}

Nilai koefisien pada gambar 2 menunjukkan hubungan antara nilai variabel independen dengan variabel keputusan untuk memilih pasar modern (1). Nilai koefisien yang bertanda positif (lebih dari 0 ) menunjukkan hubungan yang berbanding lurus antara nilai variabel independen tersebut dengan variabel dependen memilih pasar modern (1). Sedangkan nilai koefisien yang bertanda negatif (kurang dari 0) menunjukkan hubungan yang berbanding terbalik antara nilai variabel independen tersebut dengan variabel dependen memilih pasar modern (1).

\begin{tabular}{|l|c|c|c|}
\hline \multicolumn{4}{|l|}{$\begin{array}{l}\text { Coefficient Estimates [segment 1] } \\
\text { Coefficient estimates of the Choice model. Coefficients in bold are statistically significant. }\end{array}$} \\
\hline \multicolumn{1}{|c|}{ Variables / Coefficient estimates } & $\begin{array}{c}\text { Coefficient } \\
\text { estimates }\end{array}$ & $\begin{array}{c}\text { Standard } \\
\text { deviation }\end{array}$ & t-statistic \\
\hline Jenis Kelamin & 0.007984154 & 0.340773 & 0.02343 \\
\hline Umur & 0.019894984 & 0.018743 & 1.06144 \\
\hline Status & 0.122815151 & 0.342498 & 0.358586 \\
\hline Pendidikan & 0.467826247 & 0.153634 & 3.045071 \\
\hline Pendapatan per Bulan & $2.44353 \mathrm{E}-07$ & $1.05 \mathrm{E}-07$ & 2.319005 \\
\hline Jarak dari rumah ke Traditional Market terdekat & 0.082331097 & 0.032754 & 2.513656 \\
\hline Jarak dari rumah ke Modern Market terdekat & -0.11734936 & 0.034604 & -3.39122 \\
\hline Jumlah Anggota Keluarga dalam Satu Rumah & 0.044374197 & 0.117246 & 0.37847 \\
\hline Const-1 & -3.01334052 & 0.886998 & -3.39724 \\
\hline Baseline & & $\mathrm{n} / \mathrm{a}$ & $\mathrm{n} / \mathrm{a}$ \\
\hline
\end{tabular}

Gambar 2. Estimasi koefisien masing-masing variabel independen

Dari hasil tersebut terlihat bahwa hampir semua variabel menunjukkan hubungan yang berbanding lurus dengan variabel keputusan memilih pasar modern, kecuali untuk variabel jarak dari rumah ke pasar modern terdekat yang bernilai negatif. Hal ini berarti semakin besar jarak dari rumah ke pasar modern terdekat maka peluang untuk memilih pasar modern sebagai tempat berbelanja juga semakin kecil.

Nilai estimasi koefisien yang dicetak tebal merupakan nilai koefisien variabel yang secara statistik (dengan menggunakan uji $t$ ) mempengaruhi secara signifikan variabel keputusan (dependent variable). Di antara 8 variabel yang diduga mempengaruhi konsumen untuk memilih pasar tradisional atau pasar modern ternyata hanya 4 variabel yang bisa dianggap mempengaruhi secara signifikan. Keempat variabel tersebut adalah pendidikan $\left(X_{4}\right)$, pendapatan per bulan $\left(X_{5}\right)$, Jarak dari rumah ke pasar tradisional terdekat $\left(X_{6}\right)$, serta jarak dari rumah ke pasar modern terdekat $\left(X_{7}\right)$. Sedangkan keempat variabel lain seperti jenis kelamin $\left(X_{1}\right)$, umur $\left(X_{2}\right)$, status $\left(X_{3}\right)$, dan jumlah anggota keluarga $\left(X_{8}\right)$ secara 
statistik dianggap tidak mempengaruhi secara signifikan terhadap variabel keputusannya. Secara umum, persamaan yang digunakan adalah sebagai berikut:

$$
\begin{aligned}
\boldsymbol{Y}= & -3,013+0,079 X 1+0,019 X 2+0,123 X 3+0,468 X 4+2,443 X 5+ \\
& 0,082 X 6-0,117 X 7+0,044 X 8
\end{aligned}
$$

\section{c. Penghitungan Estimasi Probabilitas Pemilihan Keputusan}

Pada binary logistic regression, untuk menghitung nilai probabilitas keputusan digunakan rumus:

$$
\mathbf{P}(\boldsymbol{Y})=\frac{e^{\left(a+b X_{1}+c X_{2}+\cdots+n X_{n}\right)}}{1+e^{\left(a+b X_{1}+c X_{2}+\cdots+n X_{n}\right)}}
$$

Misal diketahui data sampel responden ke-199 adalah sebagai berikut:
Jenis Kelamin
$\left(X_{1}\right)=$ Perempuan $(1)$
Umur
$\left(X_{2}\right)=20$ tahun $(20)$
Status Perkawinan
$\left(X_{3}\right)=$ Menikah (1)
Pendidikan
$\left(X_{4}\right)=\operatorname{SMA}(3)$
Pendapatan per Bulan
$\left(X_{5}\right)=\operatorname{Rp} 600.000,-(600000)$
Jarak dari rumah ke pasar tradisional terdekat
$\left(X_{6}\right)=1$ Kilometer $(1)$
Jarak dari rumah ke pasar modern terdekat
$\left(X_{7}\right)=2$ Kilometer $(2)$
Jumlah anggota keluarga dalam satu rumah
$\left(X_{8}\right)=5$ orang $(5)$

Untuk menghitung probabilitas data sampel ke 199 memilih pasar modern (1) adalah sebagai berikut:

$$
\begin{aligned}
& \mathbf{P}(\mathbf{Y}: \mathbf{1})=\frac{e^{(-3,013+0,079 \times 1+0,019 \times 2+0,123 \times 3+0,468 \times 4+2,443 \times 5+0,082 \times 6-0,117 \times 7+0,044 \times 8)}}{1+e^{(-3,013+0,079 X 1+0,019 \times 2+0,123 \times 3+0,468 \times 4+2,443 \times 5+0,082 \times 6-0,117 \times 7+0,044 \times 8)}} \\
& \mathbf{P}(\mathbf{Y}: \mathbf{1})=\frac{e^{(-3,013+0,079 \times 1+0,019 \times 20+0,123 \times 1+0,468 \times 3+2,443 \times 600000+0,082 \times 1-0,117 \times 2+0,044 \times 5)}}{1+e^{(-3,013+0,079 \times 1+0,019 \times 20+0,123 \times 1+0,468 \times 3+2,443 \times 600000+0,082 \times 1-0,117 \times 2+0,044 \times 5)}} \\
& \mathbf{P}(\mathbf{Y}: \mathbf{1})=\frac{e^{-0,865}}{1+e^{-0,865}} \\
& \mathbf{P}(\mathbf{Y}: \mathbf{1})=0,296
\end{aligned}
$$

Artinya peluang data sampel ke-199 tersebut untuk memilih pasar modern sebagai tempat berbelanja adalah sebesar 0,296 atau 29,6\%. Untuk menghitung probabilitas data sampel ke 199 memilih pasar tradisional ( 0$)$ adalah sebagai berikut:

$$
\begin{aligned}
& \mathbf{P}(\mathbf{Y : 0})=1-\mathrm{P}(\mathrm{Y}: 1) \\
& \mathbf{P}(\mathbf{Y}: \mathbf{0})=1-0,296=0,704
\end{aligned}
$$

Peluang data sampel ke-199 tersebut untuk memilih pasar tradisional sebagai tempat berbelanja adalah sebesar 0,704 atau $70,4 \%$. Hasil perhitungan estimasi probabilitas pemilihan pasar modern/tradisional pada sampel ke-199 ditunjukkan pada gambar 3.

\begin{tabular}{|c|c|c|c|c|c|c|}
\hline $\begin{array}{c}\text { Respondents / Choice } \\
\text { probabilities }\end{array}$ & $\begin{array}{c}\text { Modern } \\
\text { Market Choice } \\
(1) \text { probability }\end{array}$ & $\begin{array}{c}\text { Traditional } \\
\text { Market Choice } \\
\text { (0) probability }\end{array}$ & $\begin{array}{c}\text { Predicted } \\
\text { Modern } \\
\text { Market Choice } \\
(1)\end{array}$ & $\begin{array}{c}\text { Predicted } \\
\text { Traditional } \\
\text { Market Choice } \\
\text { (0) }\end{array}$ & $\begin{array}{c}\text { Observed } \\
\text { Modern } \\
\text { Market Choice } \\
\text { (1) }\end{array}$ & $\begin{array}{c}\text { Observed } \\
\text { Traditional } \\
\text { Market Choice } \\
\text { (0) }\end{array}$ \\
\hline 199 & $\mathbf{0 . 2 9 6}$ & $\mathbf{0 . 7 0 4}$ & 0 & 1 & 0 & 1 \\
\hline
\end{tabular}

Gambar 3. Estimasi probabilitas pemilihan keputusan sampel ke-199 
Dengan melihat hasil tersebut, diperoleh kecocokan hasil prediksi regresi logistik dibandingkan dengan hasil observasi. Pada sampel ke-199, dengan menggunakan persamaan binary logistik regression didapatkan prediksi bahwa sampel akan memilih pasar tradisional. Hasil observasi menunjukkan bahwa sampel ke-199 juga ternyata memilih pasar tradisional. Untuk melihat validitas persamaan binary logistik regression, digunakan confusion matrix seperti yang ditunjukkan pada gambar 4.

\begin{tabular}{|c|c|c|}
\hline $\begin{array}{l}\text { Confusion Matr } \\
\text { Comparison of obse } \\
\text { High values in the di } \\
\text { diagonal values, ind } \\
\text { Analysis has been p } \\
\text { of the model. }\end{array}$ & $\begin{array}{l}\text { on Estim } \\
\text { ed choices } \\
\text { gonal of the } \\
\text { ate high con } \\
\text { formed on t }\end{array}$ & $\begin{array}{l}\text { tion Samp } \\
\text { d predicted } \\
\text { onfusion ma } \\
\text { ergence betı } \\
\text { e estimation }\end{array}$ \\
\hline $\begin{array}{l}\text { Observed / } \\
\text { Predicted Choice }\end{array}$ & $\begin{array}{l}\text { Modern } \\
\text { Market } \\
\text { Choice (1) }\end{array}$ & $\begin{array}{c}\text { Traditional } \\
\text { Market } \\
\text { Choice (0) }\end{array}$ \\
\hline $\begin{array}{l}\text { Modern Market } \\
\text { Choice (1) }\end{array}$ & 38 & 18 \\
\hline $\begin{array}{c}\text { Traditional Market } \\
\text { Choice (0) }\end{array}$ & 40 & 104 \\
\hline
\end{tabular}

Gambar 4. Confusion matrix pada alternatif pilihan

Diketahui dari tabel tersebut terlihat bahwa jumlah data yang dicetak tebal merupakan data yang hasil prediksi dan observasi kenyataannya menunjukkan hasil yang sama. Dari hasil matriks tersebut dapat disimpulkan bahwa jumlah data yang hasil prediksi dan observasinya sama atau tidak meleset prediksinya berjumlah 142, jauh lebih banyak dibandingkan dengan jumlah data yang hasil prediksi dan observasi kenyataannya tidak sama yaitu 58. Artinya hasil persamaan binary logistic regression bisa dikatakan cukup bisa untuk diandalkan.

\section{Kesimpulan}

Berdasarkan penelitian ini dapat disimpulkan bahwa sebagian besar responden memilih pasar tradisional sebagai tempat berbelanja dengan jumlah sebesar 122 atau $61 \%$ dari keseluruhan data sampel. Sedangkan yang memilih pasar modern hanya berjumlah 78 atau 39\% dari keseluruhan data sampel. Hal ini menunjukkan segmen pasar tradisional masih lebih banyak diminati oleh masyarakat di wilayah Kota Surakarta dibandingkan pasar modern. Dari 8 variabel yang diduga mempengaruhi keputusan konsumen untuk menentukan pilihan berbelanja di pasar modern atau tradisional, ternyata hanya 4 variabel yang mempengaruhi secara signifikan, yaitu pendidikan, pendapatan per bulan, jarak dari rumah ke pasar tradisional terdekat, serta jarak dari rumah ke pasar modern terdekat. Hasil persamaan binary logistic regression kemudian bisa dikatakan cukup handal untuk digunakan dalam menentukan/menduga probabilitas suatu data sampel memilih suatu alternatif keputusan tertentu.

\section{Daftar Pustaka}

Dwicahyani, A. R., Rosyidi, C. N., dan Pujiyanto, E. (2019). Minimizing gap of utility between consumer and producer in a duopoly market considering outsourcing decision, price, and product tolerance. Production \& Manufacturing Research, Vol. 7, No. 1, hal. 23-43.

Hosmer, D.W dan Lemeshow, S. (1989). Applied Logistic Regression. John Wiley \& Sons, New York, USA.

Kaygisiz, F., Bolat, B. A., dan Bulut D. (2019). Determining Factors Affecting Consumer's Decision to Purchase Organic Chicken Meat. Brazilian Journal of Poultry Science, Vol. 21, No. 4, hal 1-8.

Ketaren, K. dan Sianturi, N. M. (2017). Decision Making Modelling with Logistic Regression Approach. International Journal of Applied Engineering Research, Vol. 12, No., hal. 9067-9073.

Khaeri, H. dan Pawitan, G. (2018). Penerapan Model Regresi Logistik Biner pada Motif Faktor Kewirausahaan Perempuan. Prima: Jurnal Pendidikan Matematika, Vol. 2, No. 1, hal. 67-80.

Menon, B. dan Raj, J. V. P. (2012). Logistic Regression Modelling for Consumer Purchase Behaviour of Passenger Cars. AIMA Journal of Management \& Research, Vol. 6, No. 3, hal. 479-497. 